\title{
Drought-Damage Functions for the Estimation of Drought Costs under Future Projections of Climate Change
}

\begin{abstract}
Drought events and their impacts pose a considerable problem for governments, businesses and individuals. Superimposed on this is the risk of anthropogenic climate change. Climate models are increasingly being used to understand how climate change may affect future drought regimes. However, methodologies to quantify economic costs which could occur under these future scenarios are virtually non-existent. In this study historic drought events were identified in regional precipitation data using the Standardised Precipitation Index, and their magnitude quantified and linked to reported economic costs. Drought damage functions were created for Australia, Brazil, China, India, Spain/Portugal and the USA. Projections of drought magnitude for 2003-2050 were modelled using the Community Integrated Assessment System, for a range of climate and emission scenarios, and future economic costs estimated. Severe and extreme drought events were projected to cause estimated additional losses ranging between 0.04 and $9 \%$ of national GDP in Australia, the USA and Spain/Portugal under future scenarios of climate change. The combined effect on global GDP from projected long-term drought events in the countries analysed resulted in additional annual losses of 0.01 to $0.25 \%$. This is considered conservative as the analysis is representative of seven countries only; does not incorporate the possibility of successive drought events, or compounding effects on vulnerability from interactions with other extreme events. Furthermore, it excludes indirect economic effects; social and environmental losses; the possibility of increasing vulnerability due to changing socio-economic conditions; and the possibility of irreversible or systemic collapse of economies as the study highlighted that under future climate change drought magnitude may exceed current experience potentially passing thresholds of social and economic resilience. Stringent mitigation had little effect on the increasing impacts of drought in the first half of the $21^{\text {st }}$ century, so in the short-term adaptation in drought 'hot spots' will be crucial.
\end{abstract}

\section{Keywords}

Drought; Standardized Precipitation Index; Damage Functions; Integrated Assessment; Economic Costs; Climate Change

\section{Introduction}

Drought is a natural hazard which can be defined simply as resulting from a deficiency of precipitation from 'normal' conditions (Wilhite 2005). Droughts are slow onset, spatially extensive, events that can affect regions for weeks, months or years. Drought can also be defined based on the duration of the precipitation deficit and the particular impacts that evolve over time. For example, meteorological drought which relates to a deficit in precipitation from average conditions; hydrological drought which implies a departure in surface and sub-surface water supplies from average conditions; and agricultural drought related to the availability of soil moisture to support crop growth (Wilhite and BuchannanSmith 2005).

Droughts have one of the largest impacts on society of all extreme weather types, affecting over 1.5 billion people from 1980 to 2008 (EM-DAT 2012), and can have large economic impacts. The 2002 drought in the USA was estimated to have caused losses of over 20 
billion US\$ (Wilhite 2005). Evidence suggests that the economic costs of drought have been increasing over the $20^{\text {th }}$ and early $21^{\text {st }}$ century (EM-DAT 2012). It is argued that such trends are primarily due to changing socio-economic conditions and better reporting mechanisms (Höppe and Pielke 2006). However, in the future anthropogenic climate change may play a more dominant role in exacerbating impacts for certain regions as it is projected that drought affected areas are likely to increase in extent in the future (IPCC 2012).

Changing drought regimes could affect the scale of future economic impacts. Since the 1990s there has been increased focus on modelling and understanding changing patterns of extreme weather events (Meehl et al. 2000). Yet, the quantification of associated impacts is still in its infancy and consistent methodologies for economic cost assessments are still developing (Hallegatte et al. 2007; Pielke 2007). Consequently, major omissions in studies assessing the total economic costs of climate change are the impacts associated with extreme weather (Buchner et al. 2006; Tol 2009). Ignoring extreme weather events means that such studies exclude impacts that could appreciably increase cost estimates and arguably cause the greatest socio-economic impacts. Equally, the exclusion of extreme weather events from economic assessments means that the potential benefits of early, stringent mitigation in the form of avoided damages will not be recognised.

One approach to cost assessments is the use of climate damage functions which are simple relationships linking market or non-market impacts to climate indicators. However, a major barrier for estimating economic impacts of drought, as with other extreme weather events, is that of reliable and consistent impact data (Easterling et al. 2000). Damage estimates for a particular drought event can vary widely depending on the reporting body; the range and type of costs included; and the time in which estimates are reported. Additionally, the climate indicator has typically been global mean temperature change, which automatically hinders the application to drought which requires assessment at appropriate temporal and spatial scales.

To date almost no studies have attempted to provide quantitative estimates of the economic impacts of drought under future climate change, and to the best of the authors' knowledge no comprehensive economic drought damage functions exist. It is the development of a methodology to estimate potential drought losses, under future scenarios of climate change, which form the basis for this paper. Section two outlines the methodology for creating drought damage functions, results, and a discussion of findings. Section three outlines the Integrated Assessment Model CIAS (Community Integrated Assessment System) and method used to identify and quantify future drought events. Section four presents the estimates of future economic drought costs made utilising the drought damage functions. Section five discusses the results and significance of the findings, with final conclusions presented in section six.

\section{Creating Economic Drought Damage Functions}

\subsection{Drought Analysis}

The focus of the study is on Australia, Brazil, China, India, Portugal, Spain, and the USA. These countries were selected as they have been reported as suffering numerous drought events from 1940-2002 (EM-DAT 2012); they cover different geographical, climatological, and hydrological regimes; and have different economic structures. In addition these 
countries are already known to suffer water stress and are vulnerable to future climate change (Bates et al. 2008). In order to identify and quantify historical drought events the study utilises the Standardised Precipitation Index (SPI), developed by McKee et al. (1993). The SPI is a meteorological drought index based on precipitation data, and has been shown to perform better than other more complex drought indexes (Lloyd-Hughes and Saunders 2002; Keyantash and Dracup 2002). Furthermore, as precipitation deficit will have different impacts depending on the time over which it occurs the SPI can be determined for different time periods. This allows the dynamics of different types of droughts to be assessed (a full description of equations to calculate the SPI based on the gamma distribution are available in, inter alia., Lloyd-Hughes and Saunders (2002)). Drought can be categorised based on its SPI value, with each category occurring a known percentage of the time (table 1). The application of the SPI to this study is desirable as it provides a method for analysing the occurrence and intensity of drought, and also for defining drought start and end months, duration, and magnitude.

\section{[Table 1]}

\subsection{Drought event data}

In order to link characteristics of historical drought events to their economic impacts the Emergency Disaster Database (EM-DAT) was used (EM-DAT 2012). This is the only publicly available drought database that documents global drought events. The database records the occurrence and impacts of large-scale disasters providing information on the start and end dates of drought, the number of people affected, killed, and as used in this study the reported economic damage (in US\$) in the value of the year of occurrence. In the absence of multiple databases information from EM-DAT is taken as valid and hence results presented are highly dependent on the quantity and quality of the data. EM-DAT has a clear procedure in place for adding events to the database and once added the new event undergoes a validation process. In addition, the drought database was recently updated to reduce inconsistency in records and problems that arose due to the slow onset, spatially extensive, prolonged and complex characteristics of droughts (Below et al. 2007).

\subsection{Identifying and quantifying historical drought events}

The task of accurately and systematically quantifying historical drought events is not a simple one as each drought is unique, and drought characteristics can be highly variable over different time periods. In this study SPI-6 was used to represent shorter-term, seasonal drought, whilst SPI-12 was used to represent longer-term hydrological drought. Firstly, monthly SPI-6 and SPI-12 values were computed based on the gamma distribution as outlined in Lloyd-Hughes and Saunders (2002). The monthly SPI-6 and SPI-12 values were calculated for each country for $1940-2002$, based on precipitation data at a $0.5^{\circ}$ resolution from the widely used CRUTS2.1 dataset (Mitchell and Jones, 2005). The start year was set as 1940 in order to keep the length of the precipitation data record as long as possible, bearing in mind that drought event data before this time is limited and less robust.

Secondly, for each drought event reported in EM-DAT both the SPI-6 and SPI-12 time-series data were analysed. It was important to consider more than one time-period when trying to identify historic drought events as drought characteristics such as duration and magnitude can be highly variable over different time periods. Furthermore, the use of multiple time periods is valuable in capturing droughts which may only show up in the short or long-term 
and which would otherwise be excluded. Both the SPI-6 and SPI-12 time-series data were analysed for the specific states or administrative regions reported as being affected. As drought will rarely, if ever, affect an entire country (Wilhite 2005) it was hoped this approach would focus results on the drought affected area only. Bar charts of average SPI time-series data were created for each reported drought to ascertain if the event could be detected in the observed precipitation data. Drought was defined as a period where negative SPI values were identified which coincided with the approximate drought dates reported in EM-DAT (Jenkins and Warren 2014). The drought start date was defined as the first month in which the SPI became negative and the drought end date was defined as the first month in which the SPI became positive again.

Once a drought event was identified the third step was to aggregate the SPI values for the drought-affected cells. McKee et al., (1993, p.2) define drought magnitude as the absolute sum of the SPI values across the duration of the recorded drought. This has been modified in this study to encompass the spatial extent of each event. For each identified drought event equation one is used to calculate the Monthly Drought Magnitude (MDM) of the affected region for each month the drought is observed to have occurred in the SPI data, where $\mathrm{k}=$ drought month, $\mathrm{n}=$ total number of grid cells affected in month $\mathrm{k}$, and $\mathrm{j}=$ grid cells affected in month $\mathrm{k}$. Total Drought Magnitude (TDM) is then calculated using equation two, which sums the MDM over the duration of the recorded drought, where $\mathrm{m}=$ total number of months drought is observed to have occurred in the SPI data.

$$
\begin{gathered}
M D M_{k}=-\left(\sum_{j=1}^{n} S P I_{j}\right) \\
T D M=\left(\sum_{k=1}^{m} M D M_{k}\right)
\end{gathered}
$$

Both the SPI-6 and SPI-12 time-series were analysed separately for each drought event reported in EM-DAT for the countries of interest. Where a drought was identified the TDM was linked to impact data from EM-DAT on the economic damages (see Jenkins (2011) for full result tables for each country). Economic damages were reported by EM-DAT in current US\$ for the year in which the drought occurred. For multi-year droughts the start year of the event provided by EM-DAT was assumed to be the year in which US $\$$ were reported. In order to account for changing wealth and to enable the comparison of drought events over time the reported damages were inflation adjusted to 2002 US\$ based on GDP data from The World Bank (2010). Using a standard metric across time is beneficial as it means that the focus of the economic analysis will be on impacts of climate change rather than impacts of changing socio-economic conditions.

\subsection{Results and discussion}

Using regional, gridded, SPI data enabled 56 (78\%) of the drought events reported in EMDAT to be identified and quantified using the above methodology (table 2), although it should be noted that not all of the events were detected at both SPI-6 and SPI-12 time periods. However, of the 56 drought events quantified by this study only 34 events had data 
avaliable on the economic damages. Of the 16 events in the EM-DAT database that could not be quantified five were affected by the use of the pre-defined SPI time periods. For example, where a drought was extremely short and severe and was only detectable using a smaller SPI time period (e.g. SPI-3), or where multi-year droughts were identified using SPI6 and SPI-12 suggesting a longer SPI time period would be required to quantify the reported drought as a single event. Four events could not be quantified as they were not clearly detectable in the precipitation data, especially where no data was available in EM-DAT regarding the specific regions affected. Two droughts were identified in preceding or following years to those reported by EM-DAT and additional literature could not be found to validate the drought dates. Finally, as five of the reported drought events had not terminated by December 2002 they could not be fully quantified and were excluded.

[Table 2]

Conversely, drought events were also visible in the SPI time-series data which were not reported in EM-DAT, which may reflect limitations of the database. States are not required to report to EM-DAT and it is compiled from data reported in the media or by aid agencies and so smaller scale events which do not receive international assistance may fail to appear (Webster et al. 2008). Due to the validation method if the drought event is not reported by the international community in at least two suitable sources it is excluded. As an example, a severe drought was identified in the precipitation data in 1956 to 1957 in north-west China, but was not reported in EM-DAT. A recent study by Xiao et al., (2009) also identifies severe drought in north-west China in 1956 to 1958. An explanation for its exclusion may be the limited reporting of drought impacts in China to the wider international community prior to the 1980s (Schmidt et al. 2009). Hirabayashi et al., (2008) used the EM-DAT database to validate historic flood events and found similar issues. Flood events obtained statistically from a daily discharge dataset were not always included in EM-DAT, especially for regions with low populations or for regions where damage due to disasters is not well reported. However, the authors noted that most severe flood events in the daily discharge data were captured by the database.

In order to create country specific drought damage functions the relationship between TDM (referred to hereafter as drought magnitude) and economic costs from EM-DAT were assessed for the 34 events where economic data was available. Where drought events were detected at both SPI-6 and SPI-12 time periods the same economic value is used whilst the drought magnitude will differ, highlighting how drought characteristics can vary when considered at different time periods. The country specific drought damage functions are presented in figures 1a-f for SPI- 6 and SPI-12 time periods separately. Results are presented graphically in line with the presentation of other climate damage functions. Best-fit trend lines represent the most statistically significant fit to the data for SPI-6 (solid line) and SPI-12 (dashed line). Due to the limited number of drought events reported for Spain and Portugal it was decided to amalgamate the data as it was deemed that the climate characteristics of the countries were sufficiently similar, allowing the Iberian Peninsula to be included in the analysis.

[Figure 1a-f] 
The $R^{2}$ values in figure 1 suggest that there is very good correlation in the data for Australia, China, India, Spain/Portugal, and the USA, and that drought magnitude can account for 70$99 \%$ of the variance seen in the economic damages. One reason may be that damages are considered primarily agricultural and so economic impacts are expected to correlate closely to drought magnitude. It is important to highlight that that study period is for 1940-2002 only and Australia, for example, has suffered from more recent severe drought events. Whilst EM-DAT does include entries for drought events since 2002, at the time of the analysis the observed precipitation data was only available until 2002. In the future it would be beneficial to extend the analysis and see how robust the damage functions are to the inclusion of additional drought events.

For China data was only used post 1980 due to reliability concerns (Schmidt et al. 2009). This resulted in the exclusion of a drought event in 1965 estimated to cost $565 \mathrm{~m}$ US $\$$ which affects the trend heavily as it has the largest drought magnitude but relatively small economic damages compared to other events. This may reflect the fact that prior to China opening up to the international community in the early 1980 s the country may have underestimated damages to reduce international intervention (ibid.). Alternatively, the drought may have affected a region with relatively little economic activity, or it may represent an inaccurate estimation of the economic data.

The trend seen for Brazil is extremely weak suggesting that economic damages decline slightly as drought magnitude increases. This trend is heavily influenced by a drought event in 1983 which resulted in the highest drought magnitude but very low economic costs. The reported costs of drought events in Brazil were found to be strongly related to the location where they occur. Droughts in south and central Brazil affected coffee crops, a main export for Brazil, which resulted in high economic costs. Droughts in the arid northeast had lower damages as this is a poorer region dominated by more subsistence farming. This suggests that for Brazil separate regional damage functions may be more appropriate. However, drought event frequency and impact data was not sufficient enough to do this in a robust manner. In the future the use of regional economic time-series data when carrying out the loss normalisation process may also improve the accuracy of results for Brazil and other countries.

The methodology employed and drought damage functions created are promising and, with the exception of Brazil, show good correlation between magnitude of historic drought events and economic damages. This is an interesting result given that Toya and Skidmore (2007) investigate relationships between different measures of social/economic development and economic effects of natural disatsers using EM-DAT, and illustrate that many factors can influence disaster damages. As noted above one reason may be that damages are considered primarily agricultural and so economic impacts are expected to correlate closely to drought magnitude.

For most countries the damage functions reflect a liner trend in drought magnitude and damages. However exponential functions are fitted for Australia and the USA where there are a few very extreme events in terms of their magnitude and damage costs. Both these countries had the largest magnitude events and reported economic costs. In contrast India suffered an event of similar magnitude but had comparatively lower costs reflected in the linear damage function. However, for Australia, China, India and Spain/Portugal the number of data points 
on which the trends are fitted are extremely limited. Therefore, there is the possibility that the trends identified are due to sampling uncertainty. Similarly, the shape of the damage functions will also reflect this uncertainty and could change with the inclusion/exclusion of additional points, especially very extreme events in terms of magnitude and cost. Whilst it is suggested that the most severe drought events have been captured in the analysis, it is important to flag the possible effects that the inclusion of additional events would have on the shape and scale of the drought damage functions, and any subsequent economic estimates made using them. However, the drought damage functions were not expected to show perfect correlation between economic impact data and drought magnitude. As well as drought events varying between different regions and being dependent on the particular characteristics of that region, economic impacts may also differ over time due to changes in the economic structure of countries, and due to societal interactions.

In interpreting the drought damage functions it is also important to reiterate that results will depend directly on the quality and quantity of the underlying data. The first issue is that whilst 61 events could be identified and quantified using the above method only 34 of these events had data avaliable on the reported economic damages and could be used for the damage functions. Secondly, the quantity and quality of disaster loss data is of particular concern for China before the 1980s and prior to the 1970s for Australia, Europe, India, the USA and Central America. Data also improves in quality over time as prior to 1980 many smaller events may not have been included and only large scale events recorded, giving an unbalanced view of drought impacts. However, as drought events occur less frequently than other weather extremes such as floods it was decided to focus on the period of data in EMDAT from 1940-2002 so as not to restrict the amount of drought data further. Of the drought events used in the economic damage functions only two events occurred before the 1970s.

Advantages of the methodology include that the shape of the damage functions are derived directly from the drought magnitude and reported impact data, rather than reflecting the expert opinion of the author. In addition, the methodology addresses other common limitations of climate damage functions in that they are calibrated to historical climate data, historical event data and historical impact data; they are not based on single estimates from literature or on author opinion; and they are event, country and region specific.

\section{Projections of Drought Magnitude under Future Scenarios of Climate Change 3.1. The Community Integrated Assessment System (CIAS)}

In order to assess how climate change will affect global precipitation and subsequently the magnitude of drought events in the first half of the $21^{\text {st }}$ century the integrated assessment model (IAM) CIAS is used (Warren et al. 2008). CIAS has been designed to assess policy options, avoided damages and uncertainties associated with climate change (Warren et al. 2008). CIAS was driven by the IPCC Special Report on Emission Scenarios (SRES) A1FI emission scenario, which assume no climate change mitigation, and a greenhouse gas mitigation scenario provided by E3MG (Energy-Environment-Economy Global Model) (Barker et al. 2006) that results in stabilisation of $\mathrm{CO}_{2}$ at 450ppm by 2100 . Within CIAS the emission scenarios drive a simple Climate Model (SCM) MAGICC which has been tuned to emulate seven Atmosphere-Ocean General Circulation Models (AOGCMs) used within the IPCC Third Assessment Report (TAR) so that the user can force the model to emulate the behaviour of any of these (Warren et al. 2008). 
CIAS also incorporates the downscaling model ClimGen (Climate Generator) which uses pattern scaling to provide monthly precipitation data, at a $0.5^{\circ}$ resolution for observed (19012002 based on the CRUTS2.1 dataset) and future climate (2001-2100). ClimGen uses simulations from five GCMs available from the World Climate Research Programme's (WCRP's) Coupled Model Intercomparison Project phase 3 (CMIP3) multi-model dataset, each run with up to four SRES scenarios. The different patterns generated allow the range of uncertainty related to the use of different GCMs and emission scenarios to be investigated. Thus, the 'pattern scaling' approach allows the computational simplicity of SCMs and the spatial patterns of GCMs to be combined (Mitchell 2003). The results are interpolated using the ClimGen 'gamma-method' which expresses the precipitation changes seen in the GCM pattern as a fractional change from present day precipitation, and also considers inter-annual variability independently of mean precipitation changes. The observed inter-annual variability is modified according to changes in the shape parameter of the gamma distribution, which provides a measure of skewness of the distribution, derived from the selected GCM simulation (Warren et al. 2012).

The study uses the A1FI SRES emission scenario and the E3MG 450ppm CO2 stabilisation scenario, and the GCMs HADCM3, CSIRO2, and ECHAM4 for a total of six scenario runs. These GCMs were selected as they adequately sample the full range of global precipitation projection outcomes, with ECHAM4 projecting lower precipitation rates than most of other models under climate change, CSIRO2 projecting higher rates than most, and HADCM3 projecting a more common outcome.

\subsection{Modelling and quantifying future drought events}

For each of the scenario runs the precipitation data was transformed to the SPI for both SPI6 and SPI-12 time periods. As observed precipitation data from 1955-2002 were used to create future precipitation time-series data in ClimGen, with the natural variability in mean monthly precipitation trends for 1955-2002 assumed to repeat unchanged during the period 2003-2050, any changes seen in the precipitation distribution and subsequently SPI data could be attributed (in the model) to anthropogenic climate change.

When creating the drought damage functions bar graphs of the average monthly SPI values were used to identify reported drought events, at SPI-6 and SPI-12 time periods. The drought events were assessed based on the specific states/regions reported as affected in the EM-DAT database. However, such guidance on drought location was not available for future projections of drought. Consequently, countries were divided into smaller regions, to encompass specific climate regimes and provide information on regional drought regimes. This approach has been widely used in order to provide robust statements of regional climate change (Sheffield and Wood 2008; IPCC 2007b). The regions used in this study were based primarily on those defined in the above studies (figure 2 and table 3 ). However, as some of these regions were still very large they were further divided based on country specific climate change reports and information on particular precipitation regimes of the countries.

[Figure 2]

[Table 3] 
Bar charts of average monthly SPI were created for each of the regions for 2003-2050, for each scenario and for SPI- 6 and SPI-12 time periods, so that drought events could be visually identified. The same methodology was also applied to the observed data for the baseline period (1955-2003) so any changes in future drought characteristics could be compared to historic characteristics. A drought event was recorded where the SPI value reached or exceeded the threshold of -1.50 , to represent severe and extreme drought. The drought start month was recorded as the first month when the SPI value fell below zero prior to the threshold being reached and ending when the SPI value exceeded zero. The threshold was used to isolate the effects of severe and extreme drought events as it was assumed that larger magnitude events will result in the most severe economic consequences; the National Drought Mitigation Centre state that for longer time periods, such as SPI-12, SPI values below -1.50 are usually a good indicator that fairly significant impacts are occurring in agriculture and potentially other sectors; it was assumed that severe and extreme drought events would be difficult to cope with compared to more moderate events, even if future adaptation takes place; and as there is some evidence to suggest that at a global level the frequency of severe and extreme drought events will increase whilst the number of moderate events will remain stable (Burke et al. 2006).

Once drought events were identified in the time-series data drought magnitude was quantified using equations one and two. Where countries were divided into multiple regions, the same drought event could potentially encompass two or more regions. In order to avoid misinterpretation where regional drought dates coincided GIS was used to map the spatial data and identify visually if these were separate events or a single event encompassing multiple regions.

\subsection{Projections of future drought magnitude and discussion}

Drought event magnitude was computed for each country and scenario (representing the A1FI SRES emission scenario and the E3MG 450ppm CO2 stabilisation scenario, and the GCMs HADCM3, CSIRO2, and ECHAM4) to provide a range of results. For each scenario the drought magnitude of individual events was averaged for the 1955-2002 and 2003-2050 periods. Results were averaged as the method did not aim to explicitly present projections of individual events, their exact timing, or location but reflect a broader picture of changes that may occur under future climate change. Figures $3 a$ and $3 b$ display the change in average drought magnitude for 2003-2050 for the seven countries studied for SPI-6 and SPI-12 time periods.

[Figure 3]

The general direction of trends in average drought magnitude are consistent with the broad IPCC findings of Christensen et al., (2007a) for the countries assessed. The range represents the results generated under the six climate/emission scenarios simulated using emulations of three different GCMs and highlights how drought characteristics can vary, even being of a different sign, depending on the particular scenario used. Medium and longer-term drought events, reflected in figure $3 \mathrm{~b}$, are projected to be particularly severe under future climate change. This is in agreement with Vasiliades et al., (2009) who also used downscaled monthly precipitation data converted to the SPI to assess drought. One explanation may be that the SPI-12 results reflect an average annual decline in precipitation, although this decline may not be evenly distributed over seasons. In comparison, the SPI-6 
index will be more sensitive to short-term variability in the volume and intensity of precipitation.

The SPI is advantageous as it is a relatively simple index based on precipitation. However, in applying the SPI to future projections it is important to consider that whilst precipitation may be the primary factor in drought occurrence, under climate change high temperatures may have an increasingly large effect on drought events. This is particularly important as it is projected that annual average temperatures increase in all of the countries assessed in this study in the $21^{\text {st }}$ century (IPCC 2007b). This already appears to be the case in Australia where recent drought events have not been drier than recorded $20^{\text {th }}$ century droughts, but they have been accompanied by higher temperatures (CSIRO and Australian BoM 2007). Changes in temperature, radiation, atmospheric humidity, and wind speed can also affect the amount of evaporation and further exaggerate effects of decreased precipitation on surface water and run-off (IPCC 2007b), whereas this study is limited to the analysis of projected meteorological, rather than hydrological, drought.

The study used pre-defined country regions to overcome issues of spatial averaging when assessing future drought events. This method differed from that used to create the drought damage functions, where historical drought events were identified based on information from EM-DAT on the date and specific states affected. Comparing the drought frequency estimated in section 2.4 (guided by historical data on the specific states affected), and the drought frequency of events in the baseline period estimated in this section (which used coarser pre-defined country regions) highlighted that the results were similar, although fewer drought events were identified in the SPI time-series data using the pre-defined country regions. This result is to be expected as in many cases the pre-defined country regions encompassed larger areas than those analysed when creating the drought damage functions. This finding can also be explained by the additional use of a SPI threshold to define drought. That is, in creating the drought damage functions the threshold was zero as long as there was a period where negative SPI values could be identified which coincided with the drought details in EM-DAT. In modelling past and future drought events using the coarser country regions the SPI threshold was set at -1.50 and so some smaller magnitude events that only affected a single state or very small regions of a country were not captured. Conversely, for SPI-6 drought events the use of pre-defined country regions resulted in more drought events being detected in Australia and Portugal. For Australia, this was linked to the identification of drought events that occurred prior to 1965 as EM-DAT only reported drought events from 1967 onwards. For Portugal, it is postulated that the additional drought events identified may not have caused significant impacts to meet the EM-DAT criteria, or data may not have been available for the event to be included in the database. It is concluded that the use of the coarser pre-defined country regions enabled the largest magnitude drought events in 1955-2002 and 2003-2050 to be identified. As the focus of this analysis was on severe and extreme drought events only, this methodology is assumed robust.

\section{Estimating Future Economic Drought Costs}

Estimates of direct economic drought costs were made using the damage functions presented in section 2.4. Economic damages were normalised to 2002 US $\$$ when creating the damage functions with future estimates of drought costs presented in the same metric. Economic costs are presented as average annual costs as the methodology does not aim to explicitly present projections of economic costs of individual drought events for a given 
time and region. Tables 4 and 5 present the annual estimated drought costs for the observed (1955-2002) and future (2003-2050) periods, for each country, climate/emission scenario and GCM emulation, and SPI time period. No estimates are provided for Brazil, due to the very weak trend seen in the economic drought damage function. The tables highlight the large range in results gained using different GCMs compared to the similarities in results across the two emission/stabilisation scenarios. Figure $4 a-b$ presents the percentage change in annual economic costs from 1955-2002 to 2003-2050 (column 6, tables 4 and 5). The range of results shown reflect the maximum and minimum percentage change reported across the six scenarios. The black crosses highlight the average percentage change in in annual economic costs estimated across the six scenarios.

[Table 4]

[Table 5]

[Figure 4]

Average annual drought damages are projected to increase for both SPI-6 and SPI-12 drought events in Australia. For SPI-12 drought losses would be particularly devastating, increasing from $1.95 \mathrm{bn}$ US $\$$ to $35 \mathrm{bn}$ US $\$$ in 2003-2050. This reflects the range of results generated using the different GCMs (table 5). The analysis highlights that the largest magnitude SPI-6 drought event could cost the Australian economy 37bn US\$. To put this into perspective the 1981-1982 and 2002-03 drought events were estimated to cost 12.9bn and 7.9bn US\$ respectively (CSIRO and Australian BoM 2007; EM-DAT 2012) hence the cost of individual drought events could rise dramatically in the future. The largest magnitude SPI-12 drought event was projected to cost $701 \mathrm{bn}$ US\$. This value is greater than the entire Australian Economy in 2002 and highlights a serious problem when estimating costs of extremely large magnitude drought events. This can be linked to the shape and scale of the exponential damage function used, which in turn was based on limited data points, and the assumption that the trend would remain constant for drought events outside the range of historical experience. To demonstrate this, economic costs were also estimated assuming a linear damage function. Whilst this had a limited effect on cost estimates of SPI-6 drought events the largest magnitude SPI-12 drought event which was identified (under the ECHAM 450ppm scenario) was projected to cost $31 \mathrm{bn}$ US $\$$ compared to $701 \mathrm{bn}$ US $\$$ estimated using the exponential damage function.

In China average annual economic drought damages were projected to decrease during 2003-2050 for SPI-6 and SPI-12 drought events. This suggests that the effect of climate change on precipitation regimes in China is beneficial in regards to the mitigation of severe and extreme drought events and the economic damages they may impose, which has also been noted by other authors (e.g. Chen and Sun 2009). The range in results is also very small as only one drought event was projected to occur in the SPI-6 and SPI-12 data for all scenarios. Similarly, for India average annual economic drought damages were projected to decline. Drought events of a severe or extreme nature were only projected to occur for one scenario for the SPI-6 time-period, hence the small range seen in figure 4.

In Spain, in a worst case scenario average annual economic drought costs increase from 330 m US\$ in 1955-2002 to $1.8 \mathrm{bn}$ US\$ in 2003-2050 for SPI-6 drought events. The use of annualised data hides some significant variability in the economic damages of individual drought events. The largest magnitude events identified in the SPI data were estimated to 
cost Spain 25.5bn US\$ for SPI-6 droughts and 26.9bn US\$ for SPI-12 droughts, reflecting approximately $4 \%$ of the country's GDP. These values are significantly larger than historic losses reported by EM-DAT, with the most expensive drought on record estimated to have cost 5.9bn US\$. In Portugal, average annual economic costs are also projected to increase for both SPI-6 and SPI-12 droughts. The average percentage change in annual drought damages are higher for SPI-6 drought events for both Spain and Portugal, compared to SPI12 drought events, due to the higher frequency of SPI- 6 drought events.

In the USA, in a worst-case scenario annual drought losses increase from $5 \mathrm{bn}$ US $\$$ in 19552002 to 17.5 bn US $\$$ in 2003-2050 for SPI- 6 drought events. The largest magnitude SPI-6 drought event was projected to cost around 392bn US\$. In comparison, the drought event in 1980-81 which affected central and eastern parts of the USA was estimated to have cost 208bn US\$ (EM-DAT 2012). The largest magnitude SPI-12 drought was projected to cost $5,455 \mathrm{bn}$ US $\$$, equivalent to $50 \%$ of US GDP. Again, as was the case with Australia this suggests that economic costs of extremely large magnitude drought events are overestimated when using non-linear damage functions. In contrast the same drought event was estimated to cost $920 \mathrm{bn}$ US\$ if a linear damage function was assumed.

Average annual economic drought damages are presented in Table 6 as a percentage of each country's GDP, based on economic data from the World Bank (2010). For comparative purposes estimates for the USA and Australia generated using the hypothetical linear damage functions are also displayed.

[Table 6]

Additionally, average annual economic drought costs were summed across the countries analysed and compared to global GDP (in 2002 US\$) (figure 5). For SPI-6 droughts economic losses for $1955-2002$ are equivalent to $0.02 \%$ of global GDP. This increases under all the scenarios ranging from $0.03 \%$ to $0.06 \%$ of global GDP. Economic costs for SPI-12 drought events during $1955-2002$ are equivalent to $0.12 \%$ of global GDP. Costs also increase under all the scenarios ranging from $0.13 \%$ to $0.37 \%$ of global GDP. The results highlight that drought events in the countries analysed are expected to have a negative impact on global GDP in the first half of the $21^{\text {st }}$ century. The benefits of reduced drought impacts projected for India and China are outweighed by increasing economic costs in Australia, Spain, Portugal and the USA, with all scenarios resulting in greater losses as a proportion of global GDP compared to the 1955-2002 period. When using the hypothetical linear drought damage functions for Australia and the USA, losses as a proportion of global GDP still increase from 1955-2002 to 2003-2050 for SPI-6 droughts under all scenarios. Economic costs for SPI-12 drought events also increase in the future using HADCM3 and CSIRO2, although costs are less significant than presented in figure 5, and decline compared to 1955-2002 using ECHAM4.

[Figure 5]

In interpreting figure 5 it is important to emphasise that the results represent economic drought losses in seven countries only as a proportion of global GDP. It was not considered feasible to extrapolate estimates of economic drought costs to other countries as the above results were generated based on country specific drought impact data, and regional 
projections of precipitation. Nevertheless, considering drought effects under future climate change to just a handful of countries still results in noticeable impacts on global GDP.

\subsection{Discussion}

The drought damage functions created have proven to be functional tools in the estimation of future drought costs, yet it is difficult to accurately assess the robustness of the results. Annual economic costs estimated for 1955-2002 using the drought damage functions can be compared to the economic data available from EM-DAT for the same time-period. Indeed, in doing this it was found that the economic estimates generated via the damage functions were higher than those losses reported by EM-DAT. This is not surprising as economic data was only available for $61 \%$ of the drought events reported in EM-DAT, and not all drought events identified in the precipitation data were included in EM-DAT. Alternatively, this may suggest that the method overestimates economic costs in the baseline and future time periods. For the USA annual economic costs of 5 bn US $\$$ were projected for 1955-2002 for SPI-6 drought events, which is consistent with the estimate made by FEMA that drought events resulted in average annual losses of 6-8bn US\$ nationally (FEMA1995). Conversely, annual economic losses estimated using SPI-12 were considerably higher at $36 \mathrm{bn}$ US $\$$. The FEMA estimate is reported to be very rough, based mainly on agricultural drought losses, and is likely to exclude economic losses associated with mega-drought events like that of the 1950s (Hayes et al. 2004). Therefore, this area of research would benefit from the development of further data sets, methodologies and quantitative studies on the impacts of drought in the future to help validate results generated. The over-estimation of costs seen for the USA for SPI-12 drought events can also be linked to the use of the exponential damage function. Whilst a benefit of the methodology was that the shape and scale of the damage functions were fitted to actual historical impact and climate data, these functions were then assumed to remain unchanged when applied to future drought projections. Whilst drought costs can increase indefinitely under the damage functions, in reality costs may be restricted by the specific characteristics of a region and the total value of assets at risk. Furthermore, where the magnitude of future drought exceeds that of past experienced drought, estimates are based on extrapolation rather than interpolation.

The study also illustrated that the magnitude and costs of individual drought events could exceed that of historical events, potentially causing socio-economic thresholds to be exceeded beyond which the scale of economic costs could increase rapidly. Consequently, past a certain threshold a linear damage function, for example, may become non-linear, resulting in greater costs than estimated here using the stationary drought damage functions. Similarly, tipping points may exist beyond which the magnitude of a drought is so severe that there is irreversible or systemic collapse of economies. For example, a series of severe droughts may be so destructive to agriculture that the economy may pass a threshold where agriculture is no longer a viable market, resulting in a complete shift in the economic structure of a region or country. The existence of such thresholds and tipping points (Renaud et al. 2010), which were not considered in this analysis, would have large consequences for future economic costs of drought. Potentially, estimates of tipping points could be hypothesised from the existing drought damage functions e.g. the level of drought magnitude, above which the cost to a countries' GDP is deemed as unsustainable or unacceptable, could be used to define unacceptable drought risk. 
The analysis normalised economic data by adjusting for inflation, however, this is a relatively simple way to account for changing economic conditions, which does not take into account changes in wealth, assets at risk, or changing populations. Similarly, in terms of future tipping points human interactions, which may change under future socio-economic development, can also increase vulnerability to drought. For example, simulations of Amazon deforestation typically suggest declining precipitation of $\sim 20-30 \%$, thus land-use change alone could potentially cause critical thresholds to be passed (Lenton et al. 2008). Such complex interactions are not reflected by the drought damage functions. Socioeconomic interventions such as irrigation, extraction of groundwater, or other drought management/adaptation strategies that may mediate drought effects are not considered. Whilst government and institutional intervention may reduce drought losses there is also the potential for an additional threshold in terms of adaptability. For example, in the short-term effects of drought may be mitigated through increased used of ground water or irrigation systems. Yet, the ability to use such mechanisms under increasingly severe and frequent droughts may reach a threshold in the future beyond which the processes themselves, or the levels of investment, are no longer viable or sustainable (Sheffield and Wood 2011).

In interpreting the cost estimates one should also consider that there is the potential for certain countries to suffer from successive drought events. The effect of successive drought events on an economy already weakened by a preceding event may result in larger costs than estimated by this study. Similarly, the economic estimates presented here do not incorporate the possibility that a region or country may become increasingly vulnerable due to compounding impacts from interactions with other extreme weather events. Finally, results are also deemed to represent direct economic costs only, ignoring indirect costs and additional social and environmental impacts of drought.

\section{Conclusions}

Drought can affect virtually any region of the world, regardless of precipitation or temperature regime, posing a significant risk to both developed and developing countries. However, quantitative estimates of the economic losses which could occur under future scenarios of climate change are extremely limited. By investigating the relationship between historic drought events and their costs economic drought damage functions were developed to facilitate such an analysis. These drought damage functions are, to the best of the authors knowledge, the only country specific drought damage functions created to date, and improve on some of the limitations of traditional climate damage functions. Namely, their shape and scale are empirically grounded; they are calibrated to historical event data and precipitation data; and the methodology can be used to quantify drought magnitude across different countries, regions and time-scales. The methodology developed provides a first step to quantifying drought events and investigating their relationship with economic damages, at a broad scale. Data permitting, this could be built upon at a national or regional level to improve the robustness of the damage functions, and include a more in depth investigation of the relationship between droughts, socioeconomic factors and economic damages.

Severe and extreme drought events were projected to cause estimated additional losses ranging between 0.04 and $9 \%$ of national GDP in Australia, the USA and Spain/Portugal under future scenarios of climate change. The combined effect on global GDP from projected longterm (SPI-12) drought events in the countries analysed resulted in additional annual losses of 0.01 to $0.25 \%$, regardless of stringent mitigation. This is considered a conservative estimate, 
and the costs of individual drought events have the potential to rise dramatically, exceeding historic experience. However, the results must be interpreted with caution due to many modelling caveats, and as the quality and quantity of impact data remains a large issue. Accordingly, there are many potential extensions to this research useful for enhancing the robustness of the methodology and for increasing the applicability of the outputs for climate change analysis. One such step would be to further explore and quantify the uncertainty in the results presented here.

\section{References}

Barker T, Pan H, Kohler J, Warren R, Winne S (2006). Avoiding Dangerous Climate Change by Inducing Technological Progress: Scenarios Using a Large-Scale Econometric Model. In: Schellnhuber HJ, Cramer W, Nakicenovic N, Wigley T, Yohe G (eds) Avoiding Dangerous Climate Change. Cambridge: Cambridge University Press.

Bates BC, Kundzewicz ZW, Wu S, Palutikof J (eds) (2008). Climate Change and Water. Technical Paper of the Intergovernmental Panel on Climate Change. Geneva: IPCC Secretariat.

Below R, Grover-Kopec E, Dilley M (2007). Documenting drought-related Disasters. A global reassessment. The Journal of Environment \& Development, 16(3): 328-344.

Buchner B, Catenacci M, Goria A, Kuik O, Tol RSJ (2006). Climate Change: The cost of Inaction. A review of assessment studies with a focus on the methodologies used. London: Environment Agency.

Burke EJ, Brown SJ, Christidis N (2006). Modeling the Recent Evolution of Global Drought and Projections for the Twenty-First Century with the Hadley Centre Climate Model. Journal of Hydrometeorology, 7: 1113-1125.

Chen $\mathrm{H}$, Sun $\mathrm{J}$ (2009). How the 'Best' Models Project the Future Precipitation Change in China. Advances in Atmospheric Sciences, 26(4): 773-782.

Christensen JH, Hewitson B, Busuioc A, Chen A, Gao X, Held I, Jones R, Kolli RK, Kwon WT, Laprise R, Rueda VM, Mearns L, Menéndez CG, Räisänen J, Rinke A, Sarr A, Whetton P (2007). Regional Climate Projections. Climate Change 2007: The Physical Science Basis. Contribution of Working Group I to the Fourth Assessment Report of the Intergovernmental Panel on Climate Change. Cambridge: Cambridge University Press.

CSIRO, Australian BoM (2007). Climate Change in Australia - Technical Report. CSIRO and the Australian BoM: Australian Climate Change Science Programme.

Easterling DR, Evans J, Groisman PY, Karl T, Kunkel KE, Ambenje P (2000). Observed Variability and Trends in Extreme Climate Events: A Brief Review. Bulletin of the American Meteorological Society, 81(3): 417-425.

EM-DAT (2012). EM-DAT: The OFDA/CRED International Disaster Database. Université Catholique de Louvain, Brussels, Belgium. www.em-dat.net.

Federal Emergency Management Agency (FEMA) (1995). National Mitigation Strategy: Partnerships for building safer communities. FEMA, Washington DC.

Hallegatte S, Hourcade J-C, Dumas P (2007). Why economic dynamics matter in assessing climate change damages: illustration on extreme events. Ecological Economics, 62(2): 330-340.

Hayes MJ, Svoboda MD, Knutson CL, Wilhite DA (2004). Estimating the economic impacts of drought. 84th AMS annual meeting, proceedings of the 14th conference on applied climatology. Seattle, USA, January 10-16, 2004.

Hirabayashi Y, Kanae S, Emori S, Oki T, Kimoto M (2008). Global projections of changing risks of floods and droughts in a changing climate. Journal of Hydrological Sciences, 53(4): 754-772. 
Höppe P, Pielke R (2006). Workshop Summary Report. Workshop on climate change and disaster losses: Understanding and attributing trends and projections. Hohenkammer, Germany, May 25-26, 2006.

IPCC (2007a). Climate Change 2007: The Physical Science Basis. Contribution of Working Group I to the Fourth Assessment Report of the Intergovernmental Panel on Climate Change [Solomon, S., D. Qin, M. Manning, Z. Chen, M. Marquis, K.B. Averyt, M. Tignor and H.L. Miller (eds.)], Cambridge: Cambridge University Press.

IPCC (2007b). Climate Change 2007: Impacts, Adaptation and Vulnerability. Contribution of Working Group II to the Fourth Assessment Report of the Intergovernmental Panel on Climate Change [M.L. Parry, O.F. Canziani, J.P. Palutikof, P.J. van der Linden and C.E. Hanson (eds.)]. Cambridge: Cambridge University Press.

IPCC (ed) (2012). Managing the Risks of Extreme Events and Disasters to Advance Climate Change Adaptation. A Special Report of Working Groups I and II of the Intergovernmental Panel on Climate Change. Cambridge: Cambridge University Press.

Jenkins, K. (2011). Modelling the Economic and Social Consequences of Drought under Future Projections of Climate Change. PhD Thesis: Cambridge University. https://www.repository.cam.ac.uk.

Jenkins, K., Warren, R. (2014). Quantifying the impact of climate change on drought regimes using the Standardised Precipitation Index. Theoretical and Applied Climatology, DOI: 10.1007/s00704-014-1143-x.

Keyantash J, Dracup JA (2002). The Quantification of Drought: An Evaluation of Drought Indices. Bulletin of the American Meteorological Society, 83(8): 1167-1180.

Lenton TM, Held H, Kriegler E, Hall JW, Lucht W, Rahmstorf S, Schellnhuber HJ (2008). Tipping elements in the Earth's climate system. Proceedings of the National Academy of Sciences, 105(6): 1786-1793.

Lloyd-Hughes B, Saunders MA (2002). A Drought Climatology for Europe. International journal of climatology, 22: 1571-1592.

McKee TB, Doesken NJ, Kleist J (1993). The Relationship of Drought Frequency and Duration to Time Scales. Conference on Applied Climatology, Anaheim, California, 17-22 January 1993.

Meehl GA, Zwiers F, Evans J, Knutson TR, Mearns LO, Whetton P (2000). Trends in Extreme Weather and Climate Events: Issues Related to Modeling Extremes in Projections of Future Climate Change. Bulletin of the American Meteorological Society, 81(3): 427436.

Mitchell TD (2003). Pattern Scaling: An Examination of the Accuracy of the Technique for Describing Future Climates. Climatic Change, 60: 217-242.

Mitchell TD, Jones PD (2005). An Improved Method of Constructing a Database of Monthly Climate Observations and Associated High-Resolution Grids. International journal of climatology, 25: 693-712.

Pielke R (2007). Mistreatment of the economic impacts of extreme events in the Stern Review Report on the Economics of Climate Change. Global Environmental Change, 17: 302310.

Renaud FG, Birkmann J, Damm M, Gallopín GC (2010). Understanding multiple thresholds of coupled social-ecological systems exposed to natural hazards as external shocks. Natural Hazards, 55: 749-763.

Schmidt S, Kemfert C, Höppe P (2009). Tropical Cyclone Losses in the USA and the impact of climate change - A trend analysis based on data from a new approach to adjusting storm losses. Environmental Impact Assessment Review, 29(6): 359-369.

Sheffield J, Wood E, F. (2008). Projected changes in drought occurrence under future global warming from multi-model, multi-scenario, IPCC AR4 simulations. Climate Dynamics, 31: 79-105.

Sheffield J, Wood E, F. (2011). Drought: Past Problems and Future Scenarios. London: Earthscan 
The World Bank (2010). 2008 World Development Indicators Online. The World Bank. http://data.worldbank.org/data-catalog/world-development-indicators. [April 10, 2013]

Tol RSJ (2009). The Economic Effects of Climate Change. Journal of Economic Perspectives, 23(2): 29-51.

Vasiliades L, Loukas A, Patsonas G (2009). Evaluation of a statistical downscaling procedure for the estimation of climate change impacts on droughts. Natural Hazards and Earth System Sciences, 9(3):879-894.

Warren R, S. de la Nava Santos, Arnell NW, Bane M, Barker T, Barton C, Ford R, Füssel HM, Hankin RKS, Klein R, Linstead C, Kohler J, Mitchell TD, Osborn TJ, Pan H, Raper SCB, Riley G, Schellnhüber HJ, Winne S, Anderson D (2008). Development and illustrative outputs of the Community Integrated Assessment System (CIAS), a multiinstitutional modular integrated assessment approach for modelling climate change. Environmental Modelling Software, 23(5): 592-610.

Warren R, Yu R, Osborn TJ, de la Nava Santos S (2012). European drought regimes under mitigated and unmitigated climate change: application of the Community Integrated Assessment System (CIAS). Climate Research, 51(2): 105-123.

Webster M, Ginnetti J, Walker P, Coppard D, Kent R (2008). The Humanitarian Costs of Climate Change. Massachusetts: Feinstein International Centre, Tufts University.

Wilhite D, Buchannan-Smith M (2005). Drought as Hazard: Understanding the Natural and Social Context. In: Wilhite D (ed) Drought and Water Crises: Science, Technology and Management Issues. London: Taylor \& Francis.

Wilhite DA (ed) (2005). Drought and Water Crises: Science, Technology, and Management Issues. London: Taylor \& Francis.

Xiao J, Zhuang Q, Liang E, McGuire A, Moody A, Kicklighter D, Shao X, Melillo J (2009). Twentieth-Century Droughts and Their Impacts on Terrestrial Carbon Cycling in China. Earth Interactions, 13: 1-31.

\begin{tabular}{|c|c|c|}
\hline SPI Value & Category & Probability (\%) \\
\hline $2.00>$ & Extremely moist & $2.3 \%$ \\
\hline $1.50-1.99$ & Severely moist & $4.4 \%$ \\
\hline $1.00-1.49$ & Moderately moist & $9.2 \%$ \\
\hline$-0.99-0.99$ & Near Normal & $68.2 \%$ \\
\hline$-1.00--1.49$ & Moderately dry & $9.2 \%$ \\
\hline$-1.50--1.99$ & Severely dry & $4.4 \%$ \\
\hline$-2.00<$ & Extremely dry & $2.3 \%$ \\
\hline
\end{tabular}

Table 1: SPI Categories. Source: McKee et al., (1993)

\begin{tabular}{|c|c|c|}
\hline Country & $\begin{array}{c}\text { Total Number of } \\
\text { drought events reported } \\
\text { in EM-DAT 1940-2002 }\end{array}$ & $\begin{array}{c}\text { Number of reported drought } \\
\text { events visible in regional } \\
\text { precipitation data (\% of total) }\end{array}$ \\
\hline Australia & 9 & $8(89 \%)$ \\
\hline Brazil & 13 & $10(77 \%)$ \\
\hline China P Rep & 22 & $14(64 \%)$ \\
\hline India & 12 & $10(83 \%)$ \\
\hline Portugal & 2 & $1(50 \%)$ \\
\hline Spain & 4 & $4(100 \%)$ \\
\hline United States & 10 & $9(90 \%)$ \\
\hline TOTAL & $\mathbf{7 2}$ & $\mathbf{5 6}(\mathbf{7 8 \% )}$ \\
\hline
\end{tabular}

Table 2: The number of historical drought events reported in EM-DAT detectable in both or one of the regional SPI-6 and SPI-12 precipitation data sets 


\begin{tabular}{|c|c|c|c|}
\hline Name & Acronym & Latitude $\left(^{\circ}\right)$ & Longitude $\left(^{\circ}\right)$ \\
\hline Northwest Australia & NW-AUS & $27.75 \mathrm{~S}-10.25 \mathrm{~S}$ & $112.75 \mathrm{E}-138.25 \mathrm{E}$ \\
\hline Southwest Australia & SW-AUS & $43.75 \mathrm{~S}-28.25 \mathrm{~S}$ & $114.25 \mathrm{E}-138.25 \mathrm{E}$ \\
\hline Northeast Australia & NE-AUS & $27.75 \mathrm{~S}-10.25 \mathrm{~S}$ & $138.75 \mathrm{E}-153.75 \mathrm{E}$ \\
\hline Southeast Australia & SE-AUS & $43.75 \mathrm{~S}-28.25 \mathrm{~S}$ & $138.75 \mathrm{E}-153.75 \mathrm{E}$ \\
\hline Northwest Brazil & NW-BRA & $15.75 \mathrm{~S}-4.25 \mathrm{~N}$ & $73.75 \mathrm{~W}-50.25 \mathrm{~W}$ \\
\hline Northeast Brazil & NE-BRA & $15.75 \mathrm{~S}-0.25 \mathrm{~N}$ & $49.75 \mathrm{~W}-34.75 \mathrm{~W}$ \\
\hline Southern Brazil & S-BRA & $33.25 \mathrm{~S}-16.25 \mathrm{~S}$ & $57.75 \mathrm{~W}-38.75 \mathrm{~W}$ \\
\hline Northwest China & NW-CH & $36.25 \mathrm{~N}-49.25 \mathrm{~N}$ & $74.25 \mathrm{E}-100.25 \mathrm{E}$ \\
\hline Southwest China & SW-CH & $22.25 \mathrm{~N}-35.75 \mathrm{~N}$ & $79.25 \mathrm{E}-100.25 \mathrm{E}$ \\
\hline Northeast China & NE-CH & $32.75 \mathrm{~N}-50.75 \mathrm{~N}$ & $100.75 \mathrm{E}-119.75 \mathrm{E}$ \\
\hline Southeast China & SE-CH & $18.25 \mathrm{~N}-32.25 \mathrm{~N}$ & $100.75 \mathrm{E}-122.75 \mathrm{E}$ \\
\hline North-Northeast China & NNE-CH & $38.75 \mathrm{~N}-53.25 \mathrm{~N}$ & $120.25 \mathrm{E}-134.75 \mathrm{E}$ \\
\hline Northwest India & NW-IND & $18.75 \mathrm{~N}-35.75 \mathrm{~N}$ & $68.25 \mathrm{E}-79.75 \mathrm{E}$ \\
\hline Northeast India & NE-IND & $18.75 \mathrm{~N}-35.75 \mathrm{~N}$ & $80.25 \mathrm{E}-97.25 \mathrm{E}$ \\
\hline Southern India & S-IND & $8.25 \mathrm{~N}-18.35 \mathrm{~N}$ & $72.75 \mathrm{E}-84.25 \mathrm{E}$ \\
\hline Spain & SPA & $36.25 \mathrm{~N}-43.75 \mathrm{~N}$ & $9.25 \mathrm{~W}-3.25 \mathrm{E}$ \\
\hline Portugal & POR & $36.75 \mathrm{~N}-42.25 \mathrm{~N}$ & $9.25 \mathrm{~W}-6.75 \mathrm{~W}$ \\
\hline North-West USA & NW-USA & $40.75 \mathrm{~N}-48.75 \mathrm{~N}$ & $124.75 \mathrm{~W}-103.25 \mathrm{~W}$ \\
\hline South-West USA & SW-USA & $29.75 \mathrm{~N}-40.25 \mathrm{~N}$ & $124.25 \mathrm{~W}-103.25 \mathrm{~W}$ \\
\hline Central USA & C-USA & $26.25 \mathrm{~N}-48.75 \mathrm{~N}$ & $102.75 \mathrm{~W}-84.75 \mathrm{~W}$ \\
\hline Eastern USA & E-USA & $24.75 \mathrm{~N}-47.25 \mathrm{~N}$ & $84.25 \mathrm{~W}-66.75 \mathrm{~W}$ \\
\hline
\end{tabular}

Table 3: Definition of regions used in this study

\begin{tabular}{|c|c|c|c|c|c|}
\hline Country & $\begin{array}{l}\text { Emission } \\
\text { Scenario }\end{array}$ & GCM & $\begin{array}{c}\text { Estimated } \\
\text { Annual Drought } \\
\text { Cost }\end{array}$ & $\begin{array}{c}\text { Change in } \\
\text { Annual Drought } \\
\text { Cost from } \\
\text { Observed to } \\
2003-2050\end{array}$ & $\begin{array}{c}\text { Percentage } \\
\text { Change in } \\
\text { Annual Drough } \\
\text { Cost from } \\
\text { Observed to } \\
2003-2050 \\
\end{array}$ \\
\hline \multirow{7}{*}{ Australia } & $\begin{array}{c}\text { Baseline } \\
(1955-2002)\end{array}$ & -- & $1,030,619$ & -- & -- \\
\hline & \multirow{3}{*}{$\begin{array}{c}\text { A1FI } \\
(2003-2050)\end{array}$} & ECHAM4 & $2,691,787$ & $1,661,167$ & $161 \%$ \\
\hline & & HADCM3 & $1,597,934$ & 567,315 & $55 \%$ \\
\hline & & CSIRO2 & 905,399 & $-125,220$ & $-12 \%$ \\
\hline & \multirow{3}{*}{$\begin{array}{c}\text { 450ppm } \\
(2003-2050)\end{array}$} & ECHAM4 & $3,123,693$ & $2,093,074$ & $203 \%$ \\
\hline & & HADCM3 & $1,626,592$ & 595,973 & $58 \%$ \\
\hline & & CSIRO2 & 910,129 & $-120,490$ & $-12 \%$ \\
\hline \multirow{7}{*}{ China } & $\begin{array}{c}\text { Baseline } \\
(1955-2002)\end{array}$ & 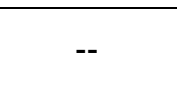 & 882,617 & -- & -- \\
\hline & \multirow{3}{*}{$\begin{array}{c}\text { A1FI } \\
(2003-2050)\end{array}$} & ECHAM4 & 242,293 & $-640,324$ & $-73 \%$ \\
\hline & & HADCM3 & 220,506 & $-662,111$ & $-75 \%$ \\
\hline & & CSIRO2 & 225,876 & $-656,740$ & $-74 \%$ \\
\hline & \multirow{3}{*}{$\begin{array}{c}\text { 450ppm } \\
(2003-2050)\end{array}$} & ECHAM4 & 244,817 & $-637,799$ & $-72 \%$ \\
\hline & & HADCM3 & 221,337 & $-661,279$ & $-75 \%$ \\
\hline & & CSIRO2 & 225,726 & $-656,891$ & $-74 \%$ \\
\hline \multirow{5}{*}{ India } & $\begin{array}{c}\text { Baseline } \\
(1955-2002)\end{array}$ & -- & 70,720 & -- & -- \\
\hline & \multirow{4}{*}{$\begin{array}{c}\text { A1FI } \\
(2003-2050)\end{array}$} & ECHAM4 & 0 & 0 & $-100 \%$ \\
\hline & & HADCM3 & 0 & 0 & $-100 \%$ \\
\hline & & CSIRO2 & 28,011 & $-42,710$ & $-60 \%$ \\
\hline & & ECHAM4 & 0 & 0 & $-100 \%$ \\
\hline
\end{tabular}




\begin{tabular}{|c|c|c|c|c|c|}
\hline & 450ppm & HADCM3 & 0 & 0 & $-100 \%$ \\
\hline & $(2003-2050)$ & CSIRO2 & 28,022 & $-42,698$ & $-60 \%$ \\
\hline \multirow{7}{*}{ Portugal } & $\begin{array}{c}\text { Baseline } \\
(1955-2002)\end{array}$ & -- & 376,195 & -- & -- \\
\hline & \multirow{3}{*}{$\begin{array}{c}\text { A1FI } \\
(2003-2050)\end{array}$} & ECHAM4 & 824,232 & 448,037 & $119 \%$ \\
\hline & & HADCM3 & 698,521 & 322,325 & $86 \%$ \\
\hline & & CSIRO2 & 406,433 & 30,237 & $8 \%$ \\
\hline & \multirow{3}{*}{$\begin{array}{c}\text { 450ppm } \\
(2003-2050)\end{array}$} & ECHAM4 & 802,666 & 426,470 & $113 \%$ \\
\hline & & HADCM3 & 665,850 & 289,655 & $77 \%$ \\
\hline & & CSIRO2 & 406,173 & 29,978 & $8 \%$ \\
\hline \multirow{7}{*}{ Spain } & $\begin{array}{c}\text { Baseline } \\
\text { (1955-2002) }\end{array}$ & -- & 329,655 & -- & -- \\
\hline & \multirow{3}{*}{$\begin{array}{c}\text { A1FI } \\
(2003-2050)\end{array}$} & ECHAM4 & $1,790,998$ & $1,461,343$ & $443 \%$ \\
\hline & & HADCM3 & $1,678,716$ & $1,349,061$ & $409 \%$ \\
\hline & & CSIRO2 & 672,134 & 342,479 & $104 \%$ \\
\hline & \multirow{3}{*}{$\begin{array}{c}\text { 450ppm } \\
(2003-2050)\end{array}$} & ECHAM4 & $1,640,530$ & $1,310,875$ & $398 \%$ \\
\hline & & HADCM3 & $1,457,221$ & $1,127,566$ & $342 \%$ \\
\hline & & CSIRO2 & 671,118 & 341,463 & $104 \%$ \\
\hline \multirow{7}{*}{ USA } & $\begin{array}{c}\text { Baseline } \\
(1955-2002)\end{array}$ & -- & $5,011,213$ & -- & -- \\
\hline & \multirow{3}{*}{$\begin{array}{c}\text { A1FI } \\
(2003-2050)\end{array}$} & ECHAM4 & $6,340,576$ & $1,329,363$ & $27 \%$ \\
\hline & & HADCM3 & $4,511,781$ & $-499,432$ & $-10 \%$ \\
\hline & & CSIRO2 & $17,558,660$ & $12,547,447$ & $250 \%$ \\
\hline & \multirow{3}{*}{$\begin{array}{c}\text { 450ppm } \\
(2003-2050)\end{array}$} & ECHAM4 & $6,569,432$ & $1,558,219$ & $31 \%$ \\
\hline & & HADCM3 & $4,494,265$ & $-516,948$ & $-10 \%$ \\
\hline & & CSIRO2 & $16,774,378$ & $11,763,165$ & $235 \%$ \\
\hline
\end{tabular}

Table 4: Economic estimates of future SPI-6 drought events in 2002 US\$ (000's).

\begin{tabular}{|c|c|c|c|c|c|}
\hline Country & $\begin{array}{l}\text { Emission } \\
\text { Scenario }\end{array}$ & GCM & $\begin{array}{c}\text { Estimated } \\
\text { Annual Drought } \\
\text { Cost }\end{array}$ & $\begin{array}{c}\text { Absolute } \\
\text { Change in } \\
\text { Annual Drought } \\
\text { Cost from } \\
\text { observed to } \\
2003-2050\end{array}$ & $\begin{array}{c}\text { Percentage } \\
\text { change in } \\
\text { Annual Drought } \\
\text { Cost from } \\
\text { observed to } \\
2003-2050\end{array}$ \\
\hline \multirow{7}{*}{ Australia } & $\begin{array}{c}\text { Baseline } \\
(1955-2002)\end{array}$ & -- & $1,956,644$ & 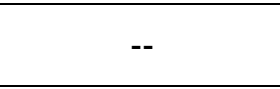 & -- \\
\hline & \multirow{3}{*}{$\begin{array}{c}\text { A1FI } \\
(2003-2050)\end{array}$} & ECHAM4 & $33,717,025$ & $31,760,381$ & $1623 \%$ \\
\hline & & HADCM3 & $2,877,107$ & 920,463 & $47 \%$ \\
\hline & & CSIRO2 & $1,560,497$ & $-396,147$ & $-20 \%$ \\
\hline & \multirow{3}{*}{$\begin{array}{c}\text { 450ppm } \\
(2003-2050)\end{array}$} & ECHAM4 & $35,152,379$ & $33,195,735$ & $1697 \%$ \\
\hline & & HADCM3 & $3,132,850$ & $1,176,207$ & $60 \%$ \\
\hline & & CSIRO2 & $1,623,617$ & $-333,027$ & $-17 \%$ \\
\hline \multirow{7}{*}{ China } & $\begin{array}{c}\text { Baseline } \\
(1955-2002)\end{array}$ & -- & 578,869 & -- & -- \\
\hline & \multirow{3}{*}{$\begin{array}{c}\text { A1FI } \\
(2003-2050)\end{array}$} & ECHAM4 & 537,897 & $-40,972$ & $-7 \%$ \\
\hline & & HADCM3 & 443,118 & $-135,751$ & $-23 \%$ \\
\hline & & CSIRO2 & 468,667 & $-110,202$ & $-19 \%$ \\
\hline & \multirow{3}{*}{$\begin{array}{c}\text { 450ppm } \\
(2003-2050)\end{array}$} & ECHAM4 & 540,264 & $-38,605$ & $-7 \%$ \\
\hline & & HADCM3 & 435,655 & $-143,214$ & $-25 \%$ \\
\hline & & CSIRO2 & 468,028 & $-110,840$ & $-19 \%$ \\
\hline \multirow{5}{*}{ India } & $\begin{array}{c}\text { Baseline } \\
(1955-2002)\end{array}$ & -- & 16,111 & -- & -- \\
\hline & \multirow{4}{*}{$\begin{array}{c}\text { A1FI } \\
(2003-2050)\end{array}$} & ECHAM4 & 0 & 0 & $-100 \%$ \\
\hline & & HADCM3 & 0 & 0 & $-100 \%$ \\
\hline & & CSIRO2 & 0 & 0 & $-100 \%$ \\
\hline & & ECHAM4 & 0 & 0 & $-100 \%$ \\
\hline
\end{tabular}




\begin{tabular}{|c|c|c|c|c|c|}
\hline & 450ppm & HADCM3 & 0 & 0 & $-100 \%$ \\
\hline & $(2003-2050)$ & CSIRO2 & 0 & 0 & $-100 \%$ \\
\hline \multirow{7}{*}{ Portugal } & $\begin{array}{c}\text { Baseline } \\
(1955-2002)\end{array}$ & -- & 213,635 & -- & -- \\
\hline & \multirow{3}{*}{$\begin{array}{c}\text { A1FI } \\
(2003-2050)\end{array}$} & ECHAM4 & 306,042 & 92,407 & 43 \\
\hline & & HADCM3 & 316,702 & 103,067 & 48 \\
\hline & & CSIRO2 & 140,271 & $-73,364$ & -34 \\
\hline & \multirow{3}{*}{$\begin{array}{c}\text { 450ppm } \\
(2003-2050)\end{array}$} & ECHAM4 & 471,563 & 257,928 & 121 \\
\hline & & HADCM3 & 400,069 & 186,434 & 87 \\
\hline & & CSIRO2 & 135,873 & $-77,762$ & -36 \\
\hline \multirow{7}{*}{ Spain } & $\begin{array}{c}\text { Baseline } \\
(1955-2002)\end{array}$ & -- & 374,575 & -- & -- \\
\hline & \multirow{3}{*}{$\begin{array}{c}\text { A1FI } \\
(2003-2050)\end{array}$} & ECHAM4 & 919,643 & 545,068 & 146 \\
\hline & & HADCM3 & 780,950 & 406,375 & 108 \\
\hline & & CSIRO2 & 354,799 & $-19,776$ & -5 \\
\hline & \multirow{3}{*}{$\begin{array}{c}\text { 450ppm } \\
(2003-2050)\end{array}$} & ECHAM4 & $1,071,282$ & 696,707 & 186 \\
\hline & & HADCM3 & 825,978 & 451,404 & 121 \\
\hline & & CSIRO2 & 353,915 & $-20,660$ & -6 \\
\hline \multirow{7}{*}{ USA } & $\begin{array}{c}\text { Baseline } \\
(1955-2002)\end{array}$ & -- & $35,811,162$ & -- & -- \\
\hline & \multirow{3}{*}{$\begin{array}{c}\text { A1FI } \\
(2003-2050)\end{array}$} & ECHAM4 & $7,243,484$ & $-28,567,678$ & $-80 \%$ \\
\hline & & HADCM3 & $93,896,437$ & $58,085,275$ & $162 \%$ \\
\hline & & CSIRO2 & $118,451,286$ & $82,640,124$ & $231 \%$ \\
\hline & \multirow{3}{*}{$\begin{array}{c}\text { 450ppm } \\
(2003-2050)\end{array}$} & ECHAM4 & $7,243,078$ & $-28,568,085$ & $-80 \%$ \\
\hline & & HADCM3 & $93,961,890$ & $58,150,728$ & $162 \%$ \\
\hline & & CSIRO2 & $119,463,443$ & $83,652,281$ & $234 \%$ \\
\hline
\end{tabular}

Table 5: As table 4 but for SPI-12 drought events

\begin{tabular}{|c|c|c|}
\hline \multirow{2}{*}{ Country } & \multicolumn{2}{|c|}{$\begin{array}{c}\text { Average annual \% loss of GDP } \\
\text { from future drought events } \\
\text { ( } \mathbf{m i n}, \mathbf{m a x})\end{array}$} \\
\cline { 2 - 3 } & SPI-6 & SPI-12 \\
\hline \multirow{2}{*}{ Australia } & 0.47 & 3.38 \\
& $(0.24,0.81)$ & $(0.41,9.13)$ \\
\hline \multirow{2}{*}{ Australia (linear) } & 0.43 & 0.46 \\
& $(0.27,0.65)$ & $(0.16,0.85)$ \\
\hline \multirow{2}{*}{ China } & 0.02 & 0.03 \\
& $(0.02,0.02)$ & $(0.03,0.04)$ \\
\hline India & 0.002 & 0.00 \\
& $(0.00,0.01)$ & $(0.00,0.00)$ \\
\hline Portugal & 0.53 & 0.25 \\
Spain & $(0.34,0.69)$ & $(0.11,0.34)$ \\
\hline USA & 0.20 & 0.11 \\
& $(0.10,0.27)$ & $(0.05,0.16)$ \\
\hline \multirow{2}{*}{ USA (linear) } & 0.09 & 0.71 \\
& $(0.04,0.17)$ & $(0.07,1.15)$ \\
\hline
\end{tabular}

Table 6: Average annual economic drought costs in 2003-2050 as a percentage of country GDP (in 2002 US\$). Numbers in brackets represent the minimum and maximum range arising from use of different emissions scenarios and GCM emulations. 


\section{Figure Captions}

Figure 2a-f: Country specific drought damage functions: The relationship between drought magnitude (calculated using the 1940-2002 SPI data (except for China)) and the reported economic damages from the EM-DAT dataset (solid line = SPI-6, dashed line = SPI-12).

Figure 2: Country regions used in this study (defined in table 3)

Figure 3a-b: Change in drought magnitude for 2003-2050 compared to 1955-2002 using ECHAM4, HADCM3 and CSIRO2 and the A1FI and 450ppm scenarios. Black crosses indicate mean values.

Figure 4a-b: The percentage change in annual economic damages for 2003-2050 compared to 1955-2002 modelled using the GCMs ECHAM4, HADCM3 and CSIRO2 and the A1FI and 450ppm scenarios. Values given represent the maximum and minimum percentage change reported. The black crosses indicate the average value calculated across all the scenario runs presented in column 6 , tables 4 and 5.

Figure 5: Average annual economic costs of SPI-6 and SPI-12 drought events in Australia, China, India, Portugal, Spain, and the USA presented as a percentage of global GDP (2002 US\$), for various scenarios (the dotted and dashed lines represent the 1955-2002 losses for SPI-6 and SPI-12 respectively) 


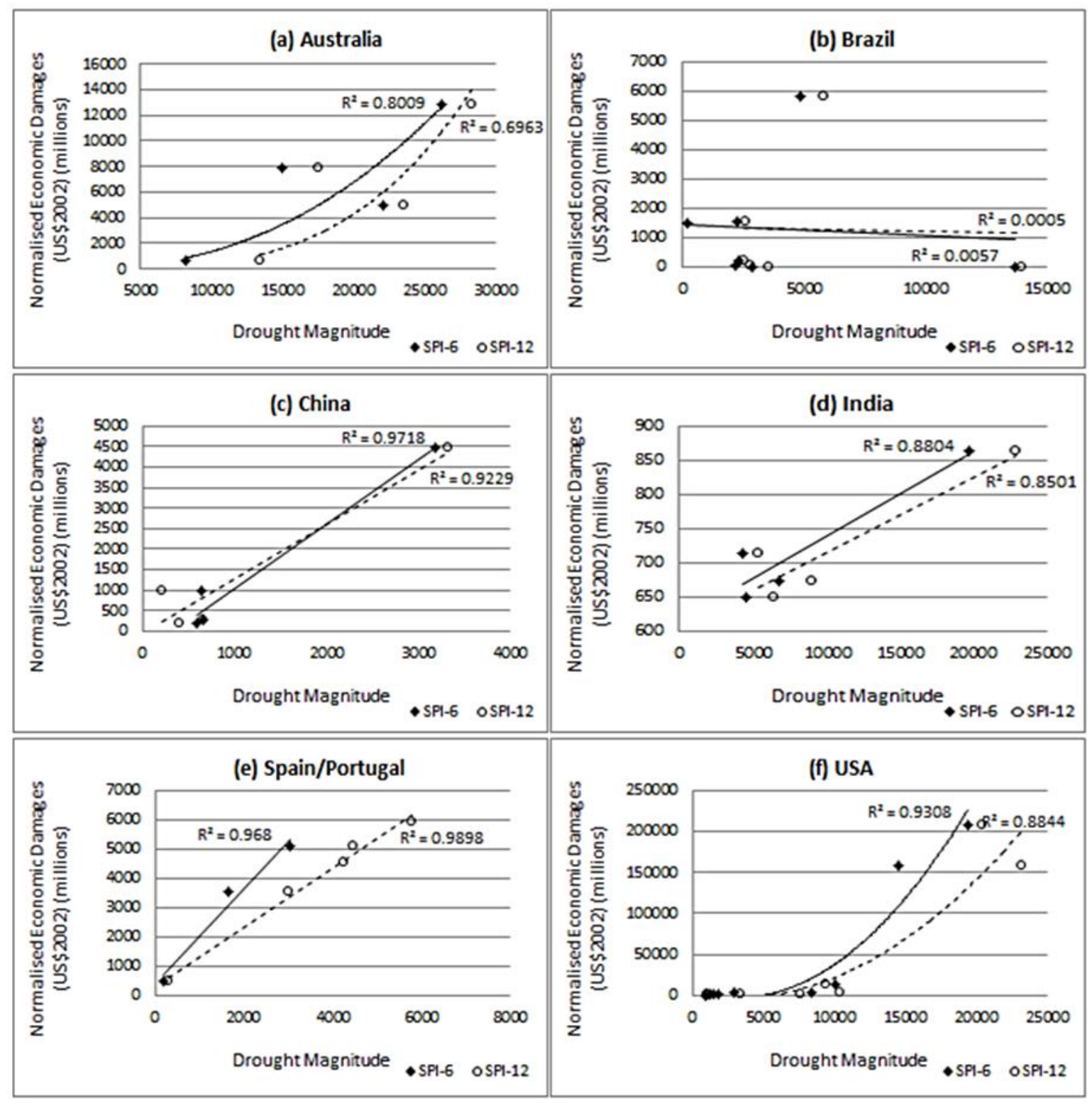

Figure 2a-f: Country specific drought damage functions: The relationship between drought magnitude (calculated using the 1940-2002 SPI data (except for China)) and the reported economic damages from the EM-DAT dataset (solid line = SPI-6, dashed line $=S P I-12$ ). 


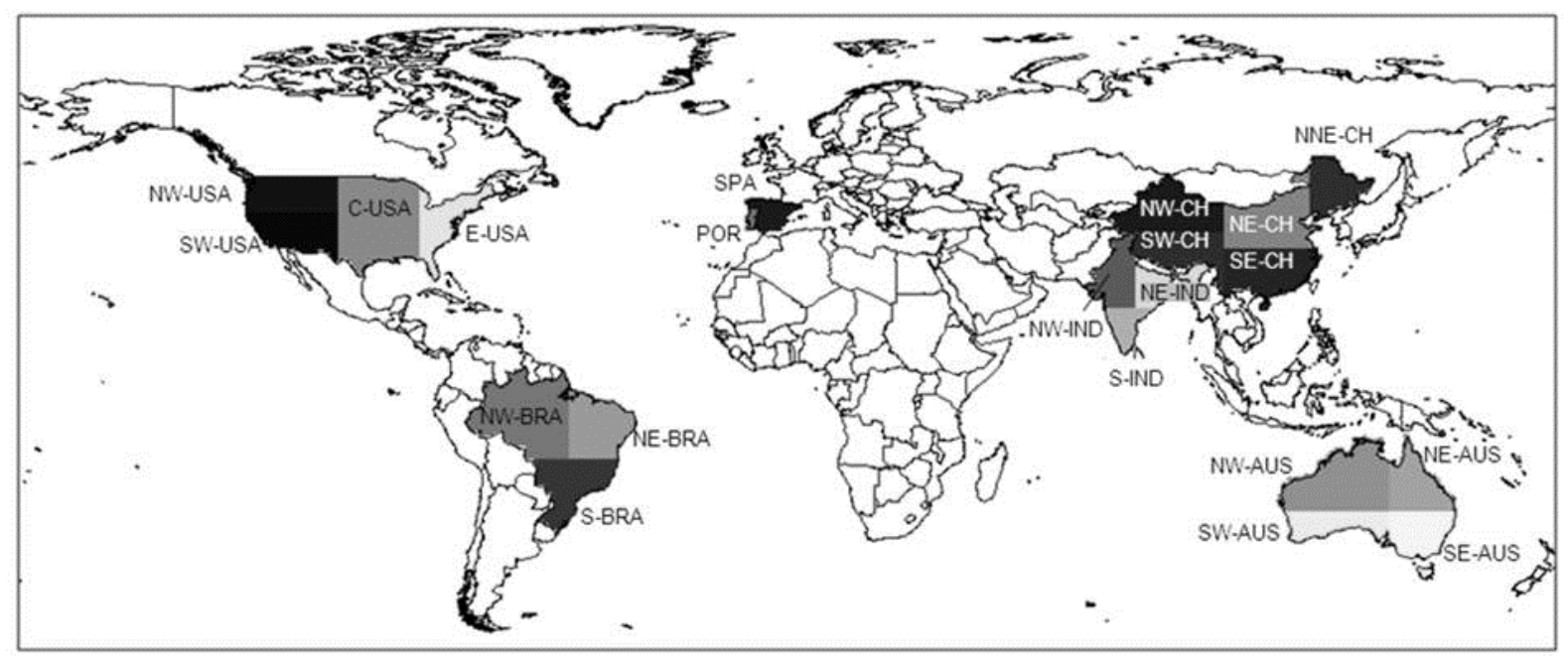

Figure 2: Country regions used in this study (defined in table 3)
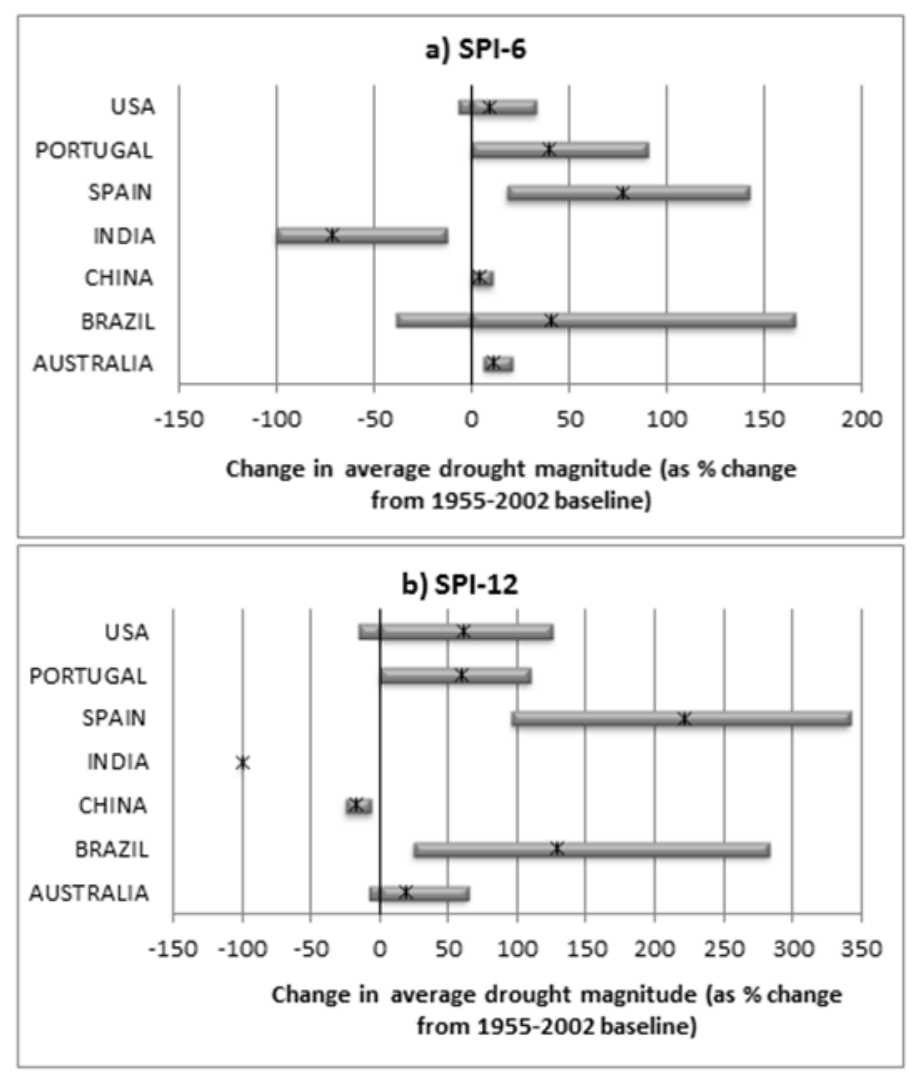

Figure 3a-b: Change in drought magnitude for 2003-2050 compared to 1955-2002 using ECHAM4, HADCM3 and CSIRO2 and the A1FI and 450ppm scenarios. Black crosses indicate mean values. 


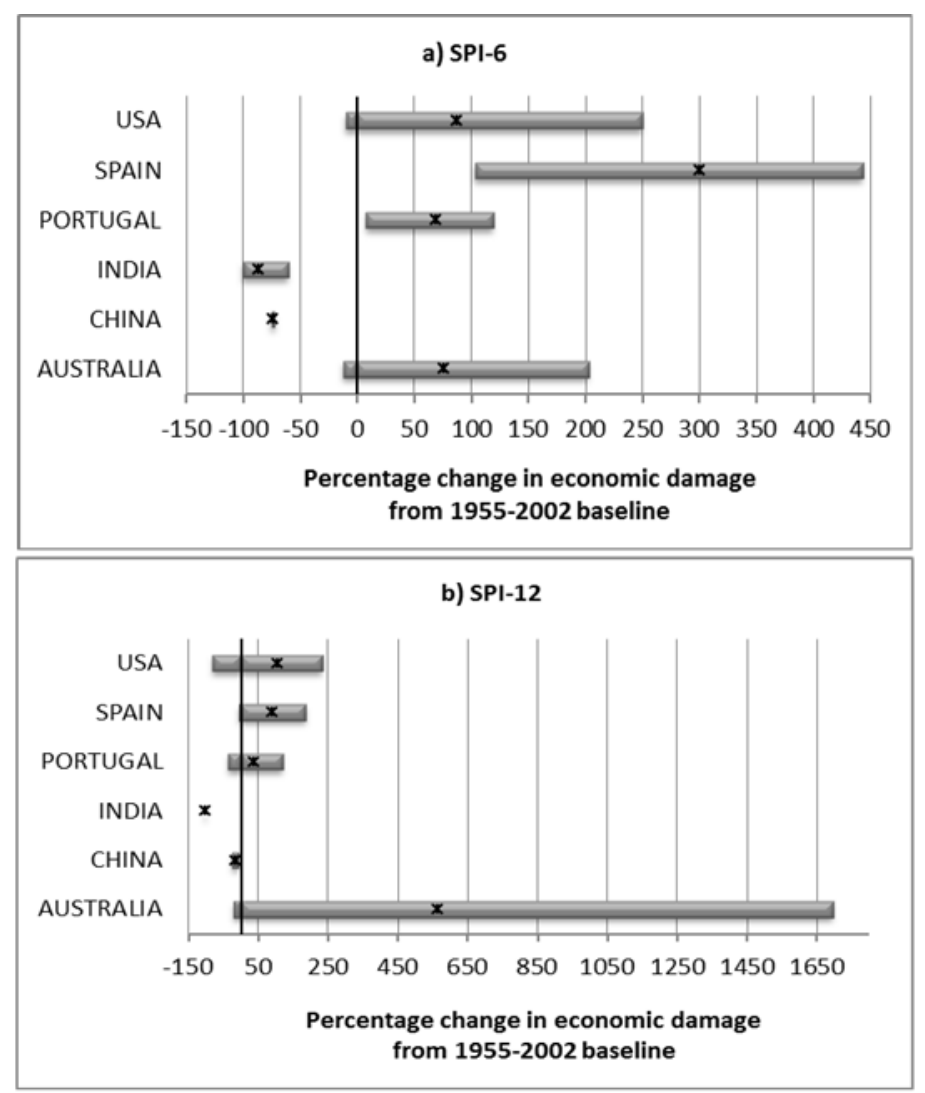

Figure 4a-b: The percentage change in annual economic damages for 2003-2050 compared to 1955-2002 modelled using the GCMs ECHAM4, HADCM3 and CSIRO2 and the A1FI and 450ppm scenarios. Values given represent the maximum and minimum percentage change reported. The black crosses indicate the average value calculated across all the scenario runs presented in column 6 , tables 4 and 5.

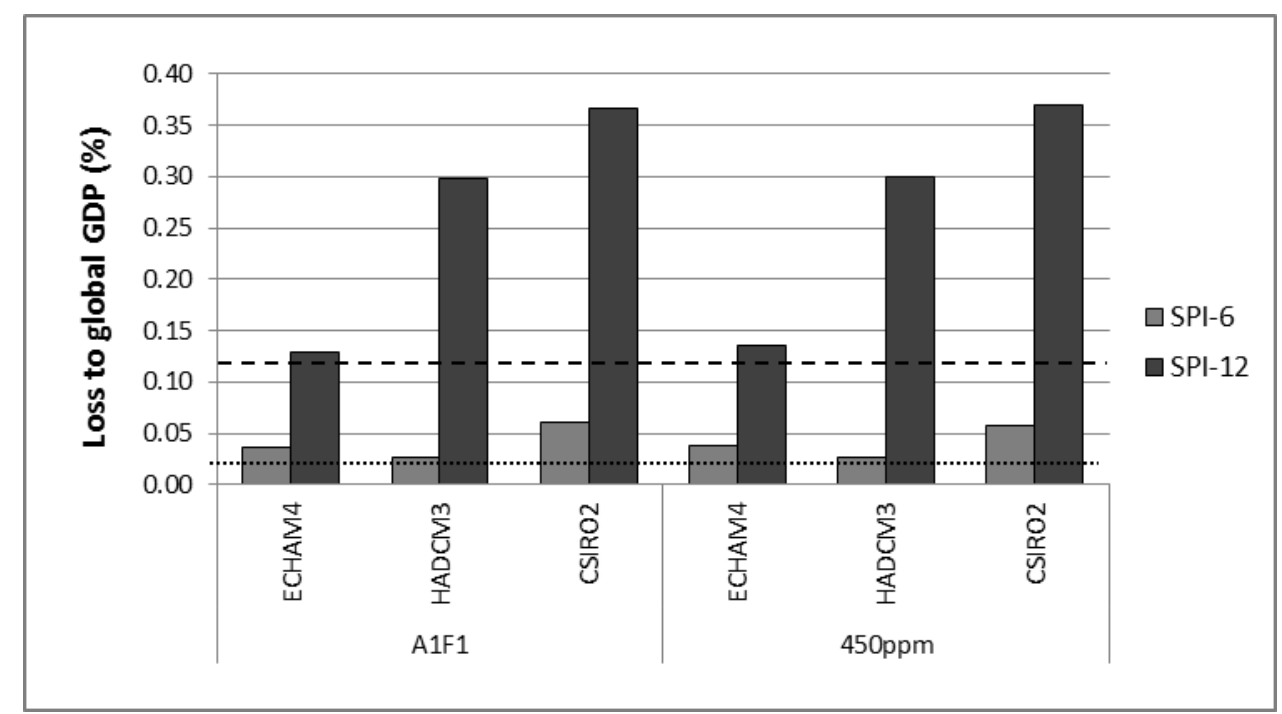

Figure 5: Average annual economic costs of SPI-6 and SPI-12 drought events in Australia, China, India, Portugal, Spain, and the USA presented as a percentage of global GDP (2002 US\$), for various scenarios (the dotted and dashed lines represent the 1955-2002 losses for SPI-6 and SPI-12 respectively) 